\title{
MINAT BELAJAR SISWA TAKHASSUS TAHFIDZ DAN NON TAHFIDZ TERHADAP MATA PELAJARAN PAI DI SMA ALI MAKSUM
}

\author{
Tutik Dinur Rofiah'1), Mu'allifah'2) \\ 1,2SMA Ali Maksum Bantul Yogyakarta \\ 1tutikdinur6@gmail.com \\ 2Unversitas Alma Ata Alifhamidea14@gmail.com
}

\begin{abstract}
ABSTRAK
Penelitian ini bertujuan untuk mengetahui perbedaan minat belajar siswa/santri Takhassus Tahfidz dan non tahfidz terhadap mata pelajaran PAI di SMA Ali Maksum Krapyak Yogyakarta. Selain itu juga untuk mengetahui seberapa besar nilai perbedaan minat belajar siswa/santri takhasus tahfidz dan non tahfidz pada mata pelajaran PAl di SMA Ali Maksum. Penelitian ini menggunanakan jenis penelitian analitis komparatif, yaitu membandingkan dua atau lebih kelompok data terdapat perbedaan aspek atau variabel yang telah diteliti dengan menggunakan uji independent t-test dikarenakan variabel dalam penelitian ini adalah 2 variabel bebas dan tidak berkorelasi. Pada penelitian ini menggunakan tiga metode pengumpulan data yaitu Angket, wawancara dan observasi. Hasil dari penelitian menunjukan bahwa Nilai rata-rata minat belajar siswa Takhasus Tahfidz sebesar 109,54 sedangkan rata-rata nilai minat anak non tahfidz sebesar 93,4 dengan besar $t$ hitung sebesar -4.728 karena $t$ hitung lebih besar dari t table dengan signifikasi 0,05 maka $\mathrm{H}_{0}$ ditolak dan $\mathrm{H}_{a}$ diterima disimpulkan bahwa minat belajar anak tahfidz lebih besar dari pada anak non tahfidz dengan nilai beda/ Mean Difference sebesar-16.14286.
\end{abstract}

Kata Kunci: Minat Belajar, Pelajaran PAI

\begin{abstract}
This study aims to see the interest in learning of Takhassus Tahfidz and non-Tahfidz students towards PAl subjects in SMA Ali Maksum Krapyak Yogyakarta. In addition, it is also to find out the value of student/ Santri Takhasus Tahfidz and non-Tahfidz interest in Islamic Education subjects at Ali Maksum High School. This research uses comparative analytical research, which is comparing two or more groups of data where there are different aspects or variables that have been studied using the independent t-test because the variables of this study are 2 independent and
\end{abstract}


uncorrelated variables. The research used three data observation methods, namely questionnaires, interviews, and observations. The results of the study showed that the average value of the students' interest in learning Takhasus Tahfidz was 109.54, while the average value of the interest in non-Tahfidz children was 93.4 with a t-count of -4.728 because $t$ count was greater than $t$ table with a significance of 0,05 then $\mathrm{HO}$ is rejected and $\mathrm{Ha}$ is accepted dis the fact that the learning interest of the Tahfidz children is greater than the non-Tahfidz children with a different value/Mean Difference of -16.14286 .

Keynote: Interest in Learning, PAI Lessons

\section{PENDAHULUAN}

Pendidikan adalah hal penting untuk mendapatkan perhatian dari berbagai pihak sebagai wujud usaha menuju kualitas kehidupan yang lebih baik. Oleh karena itu perkembangan inovasi dan pergerakan perbaikan akan terus dilaksanakan oleh tenaga pendidik maupun pelaku pendidikan sebagai langkah yang tepat dalam pengambilan keputusan dalam menyelenggarakan kegiatan belajar. Bagi seorang guru/pendidik ini adalah tugas besar untuk terus melakukan evaluasi terhadap perkembangan peserta didik baik dari segi kognitif, motorik maupun afektif.

Peserta didik selaku subjek pembelajaran, merupakan faktor terbesar yang akan membawa arah keberhasilan pembelajaran/kegiatan belajar. Sehingga guru harus mampu mengarahkan dan mengambil metode atau cara belajar yang sesuai dengan kebutuhan peserta didiknya. Kebutuhan peserta didik pastinya juga dipengaruhi oleh kharakteristik lingkungan yang ada. Di dalam kegiatan sekolah, hal yang paling utama adalah kegiatan belajar mengajar untuk tercapainya tujuan pembelajaran, maka proses belajar mengajar harus bisa diterima oleh peserta didik.(hairiyah, 2017) Dengan menitikberartkan proses pembelajaran, pendidikan sangat penting dalam mempengaruhi perilaku bermasyarakat siswanya. Pendidikan dituntut tidak hanya mengajarkan pengetahuan kepada siswanya namun juga mengajarkan pengalaman-pengalaman yang akan memotivasi dirinya dalam mengelola emosi, membina hubungan baik dengan orang lain serta menguasai perasaan diri.(SYAIFUL SAGALA, 2005)

Setiap pembelajaran peserta didik diharapkan mampu memperoleh hasil belajar yang baik, namun pada kenyataannya hasil belajar yang diperoleh tidak sesuai dengan harapan. Hal ini harus menjadi perhatian dan bahan evaluasi dalam proses 
pembelajaran yang telah dilakukan. Melton menyiratkan bahwa hasil belajar merupakan tindakan dan pertunjukan yang mengandung dan mencerminkan

Kompetensi peserta didik yang berhasil menggunakan konten, informasi, ideide dan alat-alat dalam pembelajaran. Oleh karena itu hasil belajar dapat didefinisikan sebagai kompetensi dan keterampilan yang dimiliki siswa setelah masa pembelajaran (Siti Nur Chasanah\& A. Sobandi, 2016).

Berdasarkan uraian di atas, sekolah-sekolah akan memiliki ciri khas/ programprogram serta metode-metode yang digunakan untuk pembelajaran sehingga peserta didik memiliki kompetensi dan keterampilan sesuai dengan tujuan visi dan misi sekolah.SMA Ali Maksum merupakan salah satu sekolah menengah Atas di Yogyakarta yang termasuk sekolah dengan berbasis pesantren. Anak-anak yang sekolah di sana wajib mengikuti kegiatan-kegiatan yang di program dari bangun tidur sampai tidur kembali. Di SMA Ali Maksum memiliki program khusus bagi anak-anak yang memiliki kemampuan khusus menghafal Al qur'an mereka memiliki program tersendiri dengan memperbanyak jam belajar untuk menghafal Alqur'an dan ini sedikit berbeda dengan anak-anak reguler yang setiap hari akan mengkaji kitab untuk mempertajam beban materi PAI di sekolah yang hanya sedikit pada sekolah SMA.

Praliminary yang dilakukan oleh peniliti ditemukan adanya perbedaan hasil belajar mata pelajaran PAI yang signifikan antara anak tahassus tahfidz dengan non tahfidz, Anak yang mengikuti tahassus tahfidz memiliki hasil belajar yang jauh lebih baik dibandingkan dengan anak-anak yang non tahfidz padahal anak yang non tahfidz secara menyeluruh untuk beban pendalaman materi PAI di luar pembelajaran formal, jauh lebih banyak sehingga ini menimbulkan suatu pertanyaan tersendiri. Oleh karena itu peneliti tertarik untuk mengidentifikasi permasalahan melakukan penelitian minat belajar siswa takhassus tahfidz dengan non tahfidz terhadap pembelajaran mata pelajaran PAI di SMA Ali Maksum Krapyak Yogyakarta.

\section{METODE PENELITIAN}

Penelitian yang dilakukan menggunakan metode penelitian kuantitatif, yaitu suatu proses menemukan pengetahuan yang menggunakan data berupa angkaangka sebagai alat untuk menemukan keterangan mengenai hasil yang ingin diketahui (S Margono, 2010).

Metode Penelitian ini menggunakan uji komparatif dan menggunakan analisis independent uji t-test dengan menggunakan disproportionate stratific random 
IO6 | Tarbawi : Jurnal Pendidikan Islam Vol. 17. No. 2. Juli - Desember 2020

sampling sebagai teknik pengambilan sampelnya, dan juga angket yang diberikan langsung kepada responden yaitu siswa SMA Ali Maksum Yogyakarta. Teknik sampling yang digunakan adalam simple random sampling yaitu"pengambilan anggota sampel dari populasi dilakukan secara acak tanpa memperhatikan strata yang ada dalam populasi itu(Sugiyono, 2010).

Pada penelitian ini menggunakan tiga metode pengumpulan data yaitu Angket, wawancara dan observasi. Instrumen penelitian dalam keabsahannya dilakukan dengan cara pengujan validitas dan reliabilitas (Sugiyono, 2008). Validitas adalah "suatu ukuran yang menunjukan tingkat-tingkat kevali dan atau ke shahihan sesuatu intrumen (Triyanto, 2010). Dalam uji instrumen ini, peneliti menyebar instrumen angket untuk uji validitas kepada 35 responden, dan $r$ tabel dari 35 responden adalah 0,361, nilai tersebut diambil dari tabel nilai-nilai $r$ Product Moment dengan taraf signifikansi $5 \%$.

\section{Uji Validitas Instrumen}

Hasil uji validitas instrument dihasilkan sebagai berikut:

\section{Tabel 1}

Tabel Uji Validitas Takhassus Tahfidz

Item-Total Statistics

\begin{tabular}{|l|r|r|r|} 
& $\begin{array}{c}\text { Scale Mean if } \\
\text { Item Deleted }\end{array}$ & $\begin{array}{c}\text { Scale Variance if } \\
\text { Item Deleted }\end{array}$ & $\begin{array}{c}\text { Corrected Item- } \\
\text { Total Correlation }\end{array}$ \\
\hline VAR00001 & 90.7143 & 265.681 & .650 \\
\hline VAR00002 & 90.6857 & 272.163 & .400 \\
\hline VAR00003 & 90.3429 & 271.703 & .385 \\
\hline VAR00004 & 90.6571 & 261.526 & .696 \\
\hline VAR00005 & 90.8857 & 267.104 & .511 \\
\hline VAR00006 & 90.8286 & 264.087 & .630 \\
\hline VAR00007 & 90.6000 & 271.718 & .365 \\
\hline VAR00008 & 90.7429 & 265.373 & .497 \\
\hline VAR00009 & 90.8000 & 270.576 & .402 \\
\hline VAR00010 & 90.8286 & 267.734 & .397 \\
\hline VAR00011 & 90.6857 & 264.634 & .529 \\
\hline VAR00012 & 90.8286 & 267.558 & .521 \\
\hline VAR00013 & 90.7143 & 266.916 & .417 \\
\hline VAR00014 & 90.7714 & 261.182 & .594 \\
\hline VAR00015 & 90.8571 & 268.950 & .420 \\
\hline VAR00016 & 90.8571 & 268.067 & .561 \\
\hline VAR00017 & 90.7714 & 271.299 & \\
\hline
\end{tabular}


Tarbawi : Jurnal Pendidikan Islam Vol. 17. No. 2. Juli - Desember 2020 | 107

\begin{tabular}{|l|l|l|l|}
\hline VAR00018 & 90.6857 & 256.810 & .702 \\
\hline VAR00019 & 90.3429 & 271.703 & .385 \\
\hline VAR00020 & 90.7143 & 261.151 & .669 \\
\hline VAR00021 & 90.4000 & 267.012 & .499 \\
\hline VAR00022 & 90.8286 & 267.734 & .397 \\
\hline VAR00023 & 90.7143 & 260.328 & .672 \\
\hline VAR00024 & 91.4286 & 264.193 & .620 \\
\hline VAR00025 & 90.6857 & 263.516 & .567 \\
\hline VAR00026 & 90.8286 & 264.087 & .630 \\
\hline VAR00027 & 90.7714 & 261.593 & .734 \\
\hline VAR00028 & 90.3714 & 266.887 & .454 \\
\hline VAR00029 & 90.6571 & 267.408 & .438 \\
\hline VAR00030 & 90.7143 & 258.387 & .649 \\
\hline VAR00031 & 90.8571 & 271.067 & .402 \\
\hline VAR00032 & 90.5714 & 270.311 & .368 \\
\hline VAR00033 & 90.8571 & 266.950 & .544 \\
\hline VAR00034 & 90.7714 & 261.593 & .734 \\
\hline VAR00035 & 90.8286 & 265.617 & .544 \\
\hline
\end{tabular}

Berdasarkan nilai Cronbac'h Alpha di ketahui bahwa $\mathrm{R}$ hitungterendahadalah 0.368 dan lebih besar $r$ table 0.361 , makasemua item Valid.

Tabel 2

Uji Validitas Non Tahfidz

Item-Total Statistics

\begin{tabular}{|l|r|r|r|} 
& $\begin{array}{c}\text { Scale Mean if } \\
\text { Item Deleted }\end{array}$ & $\begin{array}{c}\text { Scale Variance if } \\
\text { Item Deleted }\end{array}$ & $\begin{array}{c}\text { Corrected Item- } \\
\text { Total Correlation }\end{array}$ \\
\hline VAR00001 & 106.0571 & 121.644 & .421 \\
\hline VAR00002 & 106.4000 & 121.424 & .364 \\
\hline VAR00003 & 106.5714 & 119.664 & .533 \\
\hline VAR00004 & 106.2286 & 118.182 & .585 \\
\hline VAR00005 & 106.4286 & 121.311 & .430 \\
\hline VAR00006 & 106.4571 & 119.726 & .534 \\
\hline VAR00007 & 106.1429 & 120.655 & .523 \\
\hline VAR00008 & 106.8286 & 116.323 & .738 \\
\hline VAR00009 & 106.2857 & 120.034 & .463 \\
\hline VAR00010 & 106.2000 & 118.341 & .680 \\
\hline VAR00011 & 106.8286 & 121.440 & .491 \\
\hline VAR00012 & 106.2000 & 120.341 & .505 \\
\hline VAR00013 & 106.5714 & 118.193 & .515 \\
\hline VAR00014 & 106.2000 & 122.165 & .396 \\
\hline
\end{tabular}


IO8 | Tarbawi : Jurnal Pendidikan Islam Vol. 17. No. 2. Juli - Desember 20ZO

\begin{tabular}{|l|l|l|l|}
\hline VAR00015 & 106.8571 & 119.832 & .560 \\
\hline VAR00016 & 106.1143 & 120.575 & .524 \\
\hline VAR00017 & 106.3143 & 120.928 & .404 \\
\hline VAR00018 & 106.3714 & 119.887 & .402 \\
\hline VAR00019 & 106.4857 & 121.551 & .401 \\
\hline VAR00020 & 106.8000 & 117.459 & .663 \\
\hline VAR00021 & 106.4286 & 123.076 & .376 \\
\hline VAR00022 & 106.7429 & 118.373 & .569 \\
\hline VAR00023 & 106.8286 & 121.440 & .491 \\
\hline VAR00024 & 106.1429 & 121.008 & .490 \\
\hline VAR00025 & 106.6571 & 115.408 & .692 \\
\hline VAR00026 & 106.0571 & 121.644 & .421 \\
\hline VAR00027 & 106.2286 & 118.829 & .649 \\
\hline VAR00028 & 106.1714 & 119.911 & .534 \\
\hline VAR00029 & 106.5429 & 119.138 & .504 \\
\hline VAR00030 & 106.6857 & 116.516 & .691 \\
\hline VAR00031 & 106.4286 & 121.311 & .430 \\
\hline VAR00032 & 106.2286 & 118.182 & .585 \\
\hline VAR00033 & 106.0857 & 120.492 & .471 \\
\hline VAR00034 & 106.2286 & 118.182 & .585 \\
\hline VAR00035 & 106.6571 & 116.467 & \\
\hline & & & \\
\hline
\end{tabular}

Berdasarkan nilai conbac'h Alpha diatas nilai terkeciladalahR hitungterendahadalah $0.364>0.361$, maka semua item Valid.

\section{Uji Reliabilitas Instrumen}

Reliabilitas instrumen adalah instrumen akan memberikan nilai yang sama walaupun dilakukan pengukuran beberapa kali. Instrumen dikatakan reliabel jika instrumen tersebut memiliki nilai keajekan. Reliabilitas menunjukkan bahwa suatu instrumen cukup dapat dipercaya untuk digunakan sebagai alat pengumpulan data karena instrumen tersebut sudah baik (Slameto, 1990). 
Tabel 3

Uji Reabilitas Takhassus Tahfidz

Reliability Statistics

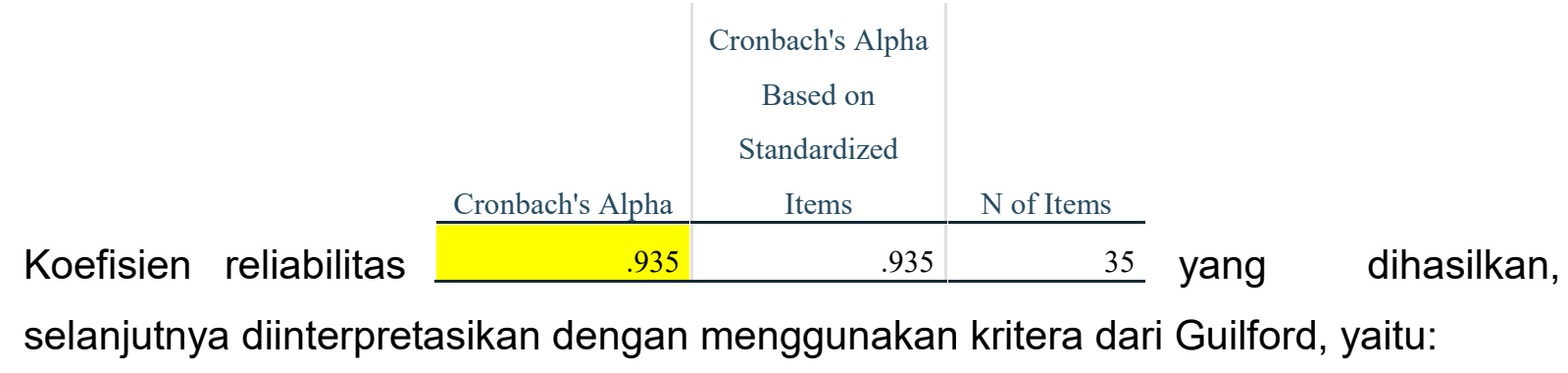

Table 4

Klasifikasi Koefisien Reliabilitas

\begin{tabular}{|c|c|}
\hline Koefisien Reliabilitas & Interpretasi \\
\hline $0,00 \leq \mathrm{r} \leq 0,20$ & Sangat Rendah \\
\hline $0,21 \leq \mathrm{r} \leq 0,40$ & Rendah \\
\hline $0,41 \leq \mathrm{r} \leq 0,60$ & Sedang/ Cukup \\
\hline $0,61 \leq \mathrm{r} \leq 0,80$ & Tinggi \\
\hline $0,81 \leq \mathrm{r} \leq 1,00$ & Sangat Tinggi \\
\hline
\end{tabular}

Dalam penelitian ini, uji reliabilitas menggunakan bantuan komputer dengan program SPSS 24.0. Butir pernyataan yang sudah dinyatakan valid dalam uji validitas ditentukan reliabilitasnya dengan kriteria sebagai berikut:

a. Jika $r$ alpha positif dan $>r$ tabel maka reliabel

b. Jika $r$ alpha negatif dan $<r$ tabel maka tidak reliabel

Tabel 4

Uji Reabilitas Non Tahfidz

Reliability Statistics

\begin{tabular}{r|c|c} 
& $\begin{array}{c}\text { Cronbach's Alpha } \\
\text { Based on } \\
\text { Standardized } \\
\text { Items }\end{array}$ & \\
\hline Cronbach's Alpha & N of Items \\
\hline .936 & .936 & 35 \\
\hline
\end{tabular}

Koefisien Reliabilitas adalah $0.935>0.81$, makatingkat reliabilitas sangat tinggi.

Dari tabel diatas dapat dilihat pada 35 butir pernyataan yang diberikan dengan tingkat signifikansi $5 \%$ dan $r$ alpha $=$ adalah 0.935 ,; ini berarti $r$ alpha $>r$ tabel yaitu $>$ 
IIO | Tarbawi : Jurnal Pendidikan Islam Vol. 17. No. 2. Juli - Desember 2020

0.81 , dan koefisien reliabilitasnya berada pada $0.81 \leq 0.935 \leq 1.0$, berarti masuk kategori sangat tinggi. Sehingga dapat dinyatakan bahwa kuesioner tersebut telah reliabel dan dapat disebarluaskan kepada responden sebagai instrumen penelitian.

\section{PEMBAHASAN}

\section{Pengertian Minat}

Minat dalam bahasa Inggris dikenal dengan istilah interest yang berarti kecenderungan besar terhadap sesuatu.(Muhibbin Syah, 2007) Minat itu tidak dibawa sejak lahir melainkan diperoleh dengan berjalannya waktu. Minat terbentuk dari interaksi antara seseorang dengan objek atau subjek meskipun dengan bantuan orang lain. Minat juga terbentuk dari kecenderungan jiwa terhadap suatu objek tertentu,biasanya disertai perasaan senang dan merasa memiliki objek yang menyenangkan(Susanto Ahmad, 2002).

Minat akan timbul dalam diri seseorang atau yang dapat menimbulkan ketertarikan, perhatian secara efektif sehingga menentukan suatu objek kegiatan yang dirasa menguntungkan, menyenangkan. minat yang kuat akan menimbulkan usaha yang gigih serius dan tidak mudah putus asa dalam menghadapi tantangan. Jika seseorang siswa memiliki rasa ingin belajar, ia akan cepat dapat mengerti dan mengingatnya (Djodi Restyo Putro, 2011). tidak adanya minat seseorang terhadap suatu pelajaran akan menimbulkan kesulitan belajar.Namun demikian, minat tanpa adanya usaha yang baik maka belajar juga sulit untuk berhasil.

Minat merupakan salah satu aspek psikis yang dapat mendorong manusia mencapai tujuan. Seseorang yang memiliki minat terhadap suatu objek, cenderung memberikan perhatian atau merasa senang yang lebih besar kepada objek tersebut. Oleh karena itu, tinggi rendahnya perhatian atau rasa senang seseorang terhadap objek dipengaruhi oleh tinggi rendahnya minat seseorang tersebut (Dalyono, 2009).

Dari beberapa penjelasan di atas minat adalah rasa tertarik atau perhatian yang mendorong manusia untuk mencapai tujuan. Minat ini akan menjadi modal aal dalam pembelajaran untuk menumbuhkan antusias rasa suka sisa terhadap pembelajaran.

\section{Pengaruh Minat Terhadap Motivasi Siswa}

Minat siswa terhadap pelajaran tertentu merupakan pendorong siswa untuk belajar lebih semangat. Adapun siswa yang memilik sikap senang terhadap suatu pelajaran maka akan tampak tekun belajar, berbeda dengan siswa yang sikapnya 
hanya menerimapelajaran apa adanya. Mereka hanya tergerak belajar tapi tidak bisa konsisten karena tidak memiliki faktor pendorongnya.

Minat merupakan faktor internal yang mempunyai peran aktifn dalam mendukung prestasi belajar, berlaku sebaliknya jika siswa tidak memiliki minat terhadap pelajaran maka siswa akancenderung sikap yang kurang simpatik, malas, dan tidak bersemangat mengikuti proses belajar mengajar.Minat dapat mempengaruhi hasil dari kualitas belajar dalam studi tertentu(Abdul Rahman Shaleh dan Muhbib Wahab, 2014). seperti sorang siswa yang memilik minat besar terhadap pelajaran matematika, maka akan memberikan perhatian lebih banyak ke pelajaran matematika daripada siswa lainnya. Kemudian, karena memberikan perhatian yang intens terhadap pelajaran itulah yang mempengaruhi siswa lebih semangat untu mencapai prestasi.

\section{Pengaruh Minat Terhadap Motivasi Siswa}

Minat siswa terhadap pelajaran tertentu merupakan pendorong siswa untuk belajar lebih semangat. Adapun siswa yang memilik sikap senang terhadap suatu pelajaran maka akan tampak tekun belajar, berbeda dengan siswa yang sikapnya hanya menerimapelajaran apa adanya. Mereka hanya tergerak belajar tapi tidak bisa konsisten karena tidak memiliki faktor pendorongnya.

Minat merupakan faktor internal yang mempunyai peran aktifn dalam mendukung prestasi belajar, berlaku sebaliknya jika siswa tidak memiliki minat terhadap pelajaran maka siswa akancenderung sikap yang kurang simpatik, malas, dan tidak bersemangat mengikuti proses belajar mengajar.Minat dapat mempengaruhi hasil dari kualitas belajar dalam studi tertentu (Abdul Rahman Shaleh dan Muhbib Wahab, 2014). seperti sorang siswa yang memilik minat besar terhadap pelajaran matematika, maka akan memberikan perhatian lebih banyak ke pelajaran matematika daripada siswa lainnya. Kemudian, karena memberikan perhatian yang intens terhadap pelajaran itulah yang mempengaruhi siswa lebih semangat untu mencapai prestasi.

\section{Faktor-faktor Mempengaruhi Minat Belajar Siswa}

Meningkatkan minat belajar siswa di pengaruhi beberapa faktor:

1. Sudut pandang siswa terhadap pelajaran

Sudut pandang yang tidak tepat terhadap pelajaran, akan membuat siswa malas untuk mendalami suatu materi, Namu sebaliknya jika Sudut pandang siswa 
IIZ | Tarbawi : Jurnal Pendidikan Islam Vol. 17. No. 2. Juli - Desember 2020

terhadap pelajaran itu positif, mengasyikkan maka siswa akan menjadi bersemangat dan gaiat belajar.

2. Kondisi Fisik dan Psikis Siswa

Proses belajar mengajar tidak hanya berpengaruh pada minat dan kesehatan fisiknya siswa, namun juga psikis, beban pikiran dan masalah yang dihadapi oleh siswa akan sangat mempengaruhi konsentrasi belajarnya siswa.

3. Hubungan Guru dan Murid

Faktor lain yang mempengaruhi siswa tidak minat belajar yaitu dipengaruhi siswa tidak menyukai guru tertentu yang berdampak tidak akan menyukai pelajaran yang disampaikan oleh guru tersebut dan itu berlaku sebaliknya. Maka siswa akan semakin bersemangat terhadap apa yang disampaikan oleh guru.

4. Metode Mengajar Guru

Suasana yang tidak efektif, monoton dan membosankan akan mempengaruhi siswa tidak bersemangat mengikuti pembelajaran. Sebaliknya suasanaya yang menarik, menyenangkan akan meningkatkan perhatian konsentrasi siswa dalam proses pembelajaran.

5. Ketertarikan Materi Pelajaran dengan Kehidupan Siswa

Setiap guru dituntut mampu membawa kesan dan pesan pelajaran yang diajarkan dengan kehidupan sehari-hari.

6. Reinforcement (Penguatan)

Setiap orang membutuhkan sebuah dorongan supaya terus berprestasi. Adapunminat dan motivasi setiap orang bisa saja berubah sewaktu-waktu baik itu naik atau menurun pada kondisi-kondisi tertentu. Kemampuan seorang guru diharapkan mampu memberikan penguatan motivasi siswa saat kondisi sedang menurun dan segara mempengaruhi " stamina" siswa untuk terus berusaha meningkat positif sehingga mampu tetap berprestasi, Sebaliknya prestasi sekecil apapun perlu diberikan apresiasi yang positif sebagai bentuk penghargaan atau usaha yang telah dilakukan oleh peserta didik. Dari kesimpulan di atas dapat disimpulkan bahwa minat belajar berpengaruh langsung positif terhadap hasil belajar siswa artinya minat belajar yang adapada diri siswa akan menyebabkan hasil belajar yang baik dan sikap siswa berpengaruh langsung positif terhadap minat belajar siswa yang baik akan meningkatkan minat belajar. 
Dari pemaparan secara teoritis mengenai minat belajar di atas dapat dikaji minat belajar PAI antara Siswa Program Tahfidz (X1), sedangkan Siswa non Tahfidz (X2), sehingga terdapat desain penelitian sebagai berikut:

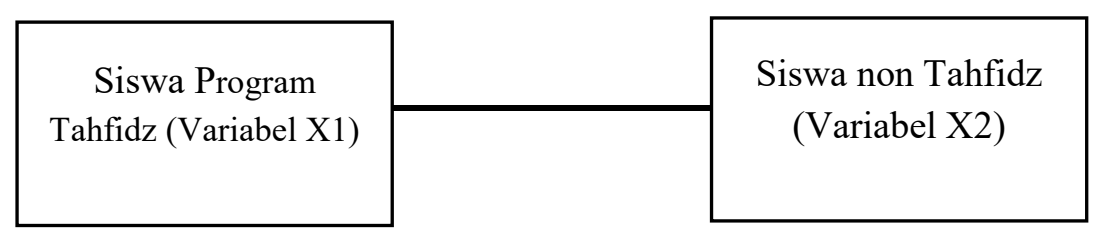

Dalam penelitian ini, jumlah populasi adalah siswa SMA Ali Maksum sebanyak 150 siswa dengan klasifikasi siswa tahfidz sejumlah 35 anak dan 115 anak non tahfidz, yang secara keseluruhan dikelompokkan menjadi 6 kelas, yaitu kelas X IPA 2, X IPS 2, XI IPA 2,XI IPS 2.XII IPA 2 dan XII IPS 1.

\section{Hipotesis Penelitian}

Dalam suatu penelitian pendidikan, proses pengumpulan data merupakan suatu hal yang sangat penting. Data yang dikumpulkan sangat terkait dengan fenomena, yang menjadi fokus penelitian. Data ini dimanfaatkan untuk membuat kesimpulan, sesuai dengan tujuan penelitian yang telah ditetapkan oleh peneliti dan menguji hipotesis yang telah dirumuskan. Hipotesis penelitian merupakan jawaban sementara terhadap permasalahan penelitian, sampai terbukti melalui data yang terkumpul(Suharsimi Arikunto dkk, 2004).

Dari definisi diatas disimpulkan bahwa suatu hipotesis masih bersifat sementara, yang masih harus dibuktikan secara empiris menggunakan pengujian rumus. Hipotesis akan diuji kebenarannya dengan pengumpulan data dan analisis penelitian. Hipotesis dalam penelitian ini akan dapat dirumuskan menjadi hipotesis analisis $(\mathrm{Ha})$ dan hipotesis nihil $(\mathrm{HO})$ sebagai berikut:

$\mathrm{Ha}$ :Terdapat perbedaan antara minat belajar PAI siswa program tahfidz dengan siswa non tahfidz di SMA Ali Maksum Krapayak Yogyakarta

HO :Tidak terdapat perbedaan minat belajar PAI antara siswa program tahfidz dengan akhlak siswa non tahfidz di SMA Ali Maksum Krapyak Yogyakarta.

\section{Analisis Data}

Dalam penelitian ini, yang akan diuji adalah apakah ada perbedaan antara minat belajar PAI siswa tahfidz dengan non tahfidz di SMA Ali Maksum Krapyak Yogyakarta. Untuk menganalisis data yang telah ada, diperlukan adanya analisis statistik dengan langkah-langkah sebagai berikut: 
II4 | Tarbawi : Jurnal Pendidikan Islam Vol. 17. No. 2. Juli - Desember 2020

1. Analisis Uji Coba Instrumen

Penelitian ini menggunakan angket sebagai instrumennya. Data angket yang sudah didapatkan kemudian dilakukan penskoran yaitu data angket yang masih dalam bentuk kualitatif diubah dalam angka-angka kuantitatif. Langkah yang diambil untuk mengubah data kualitatif menjadi kuantitatif adalah dengan memberi nilai pada setiap item jawaban pada pertanyaan angket untuk responden. Pada penskoran ini, menggunakan skala Likert yaitu skala yang banyak digunakan oleh peneliti untuk mengukur persepsi atau sikap seseorang. Skala ini menilai sikap atau tingkah laku yang diinginkan oleh peneliti dengan cara mengajukan beberapa pertanyaan kepada responden, kemudian responden tersebut diminta memberikan jawaban dalam skala ukur yang telah disediakan, misalnya selalu, sering, kadangkadang, jarang dan tidak pernah(Sukardi, 2014).

Angket yang diujikan dalam penelitian ini menggunakan 5 opsi jawaban yaitu selalu, sering, kadang-kadang, jarang dan tidak pernah. Langkah yang diambil yaitu dengan memberi skor pada setiap item pernyataan yang telah dijawab oleh responden dengan kriterian penskoran :

Tabel 5

\section{Kriteria Peskoran}

\begin{tabular}{|c|c|c|}
\hline \multirow{2}{*}{ Alernatif jawaban } & \multicolumn{2}{|c|}{ Skor pernyataan } \\
\cline { 2 - 3 } & Positif $(+)$ & Negatif (-) \\
\hline Selalu & 5 & 1 \\
\hline Sering & 4 & 2 \\
\hline Kadang-kadang & 3 & 3 \\
\hline Jarang & 2 & 4 \\
\hline Tidak pernah & 1 & 5 \\
\hline
\end{tabular}

2. Analisis Uji Persyaratan Data

a. Uji Normalitas

Uji normalitas digunakan untuk mengetahui kenormalan data yang digunakan dalam penelitian. Untuk mendeteksi apakah data yang diuji berdistribusi normal atau tidak yaitu dengan menggunakan uji Kolmogorov Smirnov, dikarenakan sampel $\leq 35$. Untuk uji normalitas ini, peneliti akan menggunakan program SPSS versi 24.0 dengan kriteria data berdistribusi normal apabila:

a. Nilai signifikansi $>5 \%$ atau 0.05 , maka data berdistribusi normal 
Tarbawi : Jurnal Pendidikan Islam Vol. 17. No. 2. Juli - Desember 2020 | II5

b. Nilai signifikansi $<5 \%$ atau 0.05 , maka data berdistribusi tidak normal

Tabel.6

Uji Normalitas

One-Sample Kolmogorov-Smirnov Test

\begin{tabular}{llr|r} 
& & NonTahfid & \\
& & $\mathrm{z}$ & Tahfidz \\
\hline $\mathrm{N}$ & & 35 & 35 \\
\hline Normal Parameters $^{\mathrm{a}, \mathrm{b}}$ & Mean & 93.4000 & 109.5429 \\
\cline { 2 - 4 } & Std. & 16.77568 & 11.25204 \\
& Deviation & & \\
\hline Most Extreme & Absolute & .116 & .089 \\
\hline Differences & Positive & .055 & .075 \\
\cline { 2 - 4 } & Negative & -.116 & -.089 \\
\hline Test Statistic & & .116 & .089 \\
\hline Asymp. Sig. (2-tailed) & & $.200^{\mathrm{c}, \mathrm{d}}$ & $.200^{\mathrm{c}, \mathrm{d}}$ \\
\hline
\end{tabular}

Nilai Signifikasi variable non tahfidz yaitu0.2> 0.05, maka Distribusi data normal

Nilai Signifikasi variable tahfidz yaitu0.2> 0.05, maka Distribusi data normal

b. Uji Homogenitas

Uji homogenitas adalah pengujian mengenai sama tidaknya variansivariansi dua buah distribusi atau lebih. Uji homogenitas digunakan untuk menunjukkan bahwa kondisi sampel yang diambil berasal dari kondisi yang sama atau homogen. Uji homogenitas yang digunakan adalah $F_{\text {hitung. }}$ Uji homogenitas sama atau tidak sama, ditentukan dengan menggunakan nilai signifikansi sebagai berikut:

1) Jika $F_{\text {hitung }}$ atau nilai signifikansi< taraf signifikansi $5 \%$ atau 0,05 , maka kedua variabel tersebut bukan berasal dari kondisi yang sama atau tidak homogen

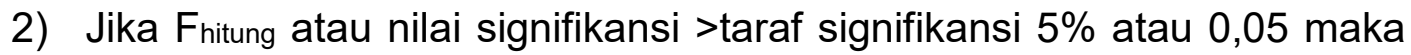
kedua variabel tersebut berasal dari kondisi sama atau homogen

\section{Tabel 7}


II6 | Tarbawi : Jurnal Pendidikan Islam Vol. 17. No. 2. Juli - Desember 2020

\section{Uji Homogenitas}

Test of Homogeneity of Variances

Minat Belajar PAI

\begin{tabular}{r|r|r|r}
$\begin{array}{c}\text { Levene } \\
\text { Statistic }\end{array}$ & \multicolumn{1}{c|}{ df1 } & \multicolumn{1}{c|}{ df2 } & \multicolumn{1}{c}{ Sig. } \\
\hline 5.336 & 1 & 68 & .024 \\
\hline Nilai Signifikasi> & 0.05, maka Data Homogen \\
Nilai Signifikasi yaitu0.024< 0.05, maka Data Homogen
\end{tabular}

3. Analisis Uji Hipotesis

Analisis ini digunakan untuk menguji hipotesis yang diajukan, yaitu untuk menguji perbedaan minat belajar antara siswa program tahfidz dengan non tahfidz. Adapun uji hipotesis dalam penelitian ini adalah menggunakan uji sampel independent $t$-test, dikarenakan variabel dalam penelitian ini adalah 2 variabel bebas dan tidak berkorelasi.

Tabel 8

Tabel Rata-rata Minat

Group Statistics

\begin{tabular}{ccr|r|r|r}
\multirow{2}{*}{ Kelas } & $\mathrm{N}$ & Mean & Std. Deviation & \multicolumn{1}{c}{$\begin{array}{c}\text { Std. Error } \\
\text { Minat }\end{array}$} \\
\cline { 2 - 7 } & 1.00 & 35 & 93.4000 & 16.77568 & 2.83561 \\
\cline { 2 - 7 } & 2.00 & 35 & 109.5429 & 11.25204 & 1.90194 \\
\hline
\end{tabular}

Rata-rata Minat Non-Tahfidz adalah sebesar 93.4b

Rata-rata Minat Tahfidz adalah sebesar 109.54

Menunjukkan rata-rata Minat Non-Tahfidz< rata-rata MinatTahfidz

\section{Tabel 9}

Tabel Uji t-Test

Independent Samples Test

t-test for Equality of Means

\begin{tabular}{l|l} 
Mean & Std. Error
\end{tabular}

Difference Difference

95\% Confidence Interval of the Difference 


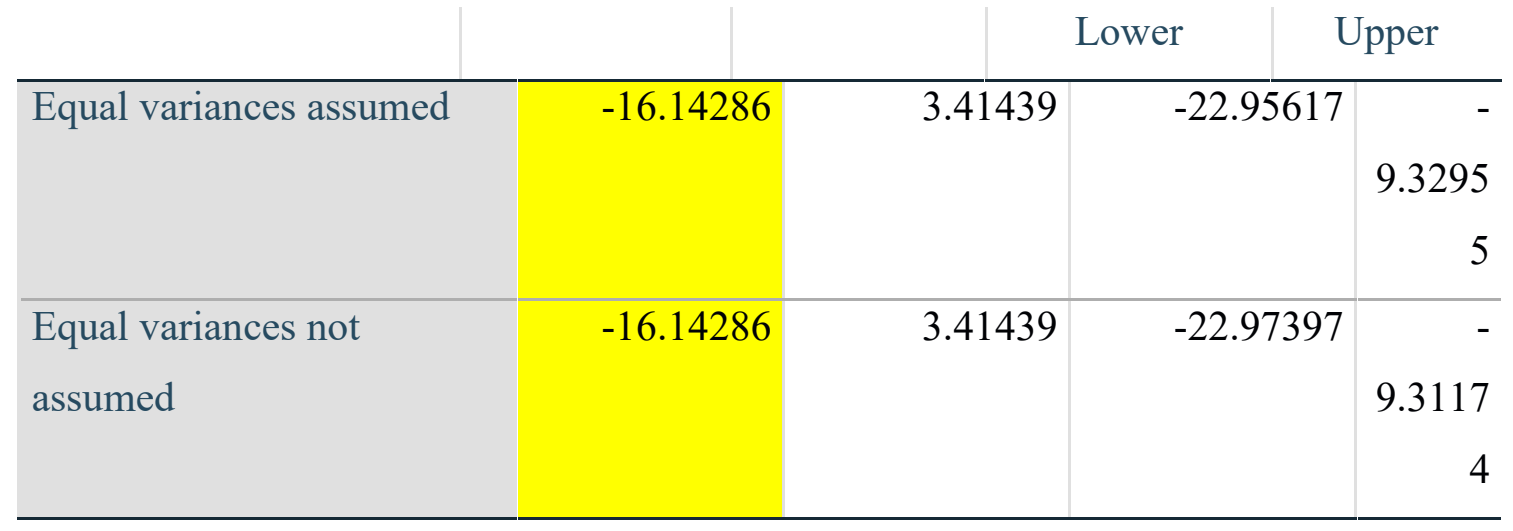

Dari table di atas menunjukan bahwa Mean Difference sebesar -16.14286. Mead different adalah selisih rata-rata minat belajar tahfidz dengan non tahfidz, hal ini menunjukkan adanya perbedaan Minat antara anak pada kelompok takhassus tahfidz dengan non tahfidz.

4. Analisis Lanjut

Setelah mengetahui hasil pengujian independent sample t-test, selanjutnya adalah melakukan analisis hipotesis dengan kriteria pengujian yaitu thitung dibandingkan dengan tabel pada taraf signifikansi $5 \%$, maka:

a. Jika thitung $<$ tabel maka $\mathrm{H}_{0}$ diterima dan $\mathrm{H}_{a}$ ditolak, artinya tidak terdapat perbedaan yang signifikan antara siswa Program tahfidz dengan siswa non tahfidz.

b. Jika thitung $>$ tabel maka $\mathrm{H}_{0}$ ditolak dan $\mathrm{H}_{a}$ diterima, yang artinya terdapat perbedaan yang signifikan antara siswa program tahfidz dengan siswa non tahfidz.

\section{Tabel 10}

Tabel Uji t-Test

Independent Samples Test

Levene's Test for Equal

of Variances

F Sig.

$\mathrm{T}$

Sig. (2-tailed) 


\begin{tabular}{l|l|l|r|r|r|}
\hline $\begin{array}{l}\text { Equal variances } \\
\text { assumed }\end{array}$ & 5.336 & .024 & -4.728 & 68 & .000 \\
\hline $\begin{array}{l}\text { Equal variances not } \\
\text { assumed }\end{array}$ & & & & & \\
\hline
\end{tabular}

Dari data di atas dapat diketahui Signifikasi $0.024<0.05$, berarti varians data homogen. Signifikasi (2-tailed) $0.000<0.05$, berarti hipotesis diterima yaitu ada perbedaan yang signifikan. T hitungsebesar -4.728 bukan berarti nilainya negative ini terjadi karena nilai minat rata-rata non-tahfidz<tahfidz.

\section{SIMPULAN}

Berdasarkan hasil penelitian yang peneliti lakukan dengan judul Perbandingan minat belajar antara siswa tahfidz dengan siswa non tahfidz di SMA Ali Maksum Krapyak Yogyakarta, dapat disimpulkan bahwa:

1. Dari 35 butir pernyataan yang diberikan dengan tingkat signifikansi $5 \%$ dan $r$ alpha $=$ adalah 0.936,; ini berarti $r$ alpha $r$ tabel yaitu $>0.81$, dan koefisien reliabilitasnya berada pada $0.81 \leq 0.935 \leq 1.0$, berarti masuk kategori sangat tinggi.

2. Selisih rata-rata minat belajar tahfidz dengan non tahfidz -16.14286 ini menunjukkan adanya perbedaan minat.

3. Terdapat perbedaan yang signifikan antara minat belajar siswa tahfidz dengan siswa non tahfidz di SMA Ali Maksum Krapyak Yogyakarta dengan nilai thitung sebesar -4.728 , dan dengan menggunakan taraf signifikan sebesar $5 \%$ dengan df sebesar 35 maka tabel $=0.024$. Karena $t$ hitunglebih besar dibandingkan $t$ tabel, maka HO ditolak dan Ha diterima, yang menunjukkan bahwa terdapat perbedaanyang signifikan antara minat belajar PAI siswa tahfidz dengan siswa non tahfidz kelas di SMA Ali Maksum Krapyak Yogyakarta.

Dari hasil perbandingan minat belajar di atas dapat disimpulkan Nilai rata-rata minat belajar siswa non tahfidz adalah sebesar 93.4 sedangkan ratarata minat belajar siswa tahfidz adalahsebesar 109.54 maka dapat disimpulkan bahwa minat belajar siswa tahfidz rata-rata minat belajar tahfidz>minat belajar 
Tarbawi : Jurnal Pendidikan Islam Vol. 17. No. 2. Juli - Desember 2020 | II9

non tahfidz. maka $\mathrm{HO}$ ditolak dan Ha diterima dan berarti terdapat pengaruh yang signifikan.

\section{DAFTAR PUSTAKA}

Abdul Rahman Shaleh dan Muhbib Wahab. (2014). Psikologi. Prenada Media.

Dalyono. (2009). Psikologi Pendidikan. Rineka Cipta.

Djodi Restyo Putro. (2011). Studi Komparasi Penggunaan Metode Ceramah Dan

Diskusi Terhadap Minat dan Prestasi Belajar Siswa dalam Pembelajaran PKN. Universitas Negeri Yogyakarta.

hairiyah. (2017). Pengaruh Kompetensi Sosial Guru Terhadap Prestasi Belajar Siswa

Pada Mata Pelajaran Akidah Akhlak Kelas VII Di Madrasah Tsanawiyah Negeri

Model Makassar," L VIII. Jurnal Kependidikan, I VIII, 139.

Muhibbin Syah. (2007). Psikologi Pendidikan dengan Pendekatan Baru. Rineka Cipta.

S Margono. (2010). Metodologi Penelitian Pendidikan. Rineka Cipta.

Siti Nur Chasanah\& A. Sobandi. (2016). Minat Belajar Sebagai determinan Hasil

Belajar Siswa. Jurnal Pendidikan Manajemen Perkantoran, I, 18-135.

Slameto. (1990). Belajar dan Faktor-faktor yang Mempengaruhinya. Rineka Cipta.

Sugiyono. (2008). Metode Penelitian Kuantitatif, Kualitatif, Dan R\&D. Alfabeta.

Sugiyono. (2010). Metode Penelitian Pendidikan. Rineka Cipta.

Suharsimi Arikunto dkk. (2004). Evaluasi Program Pendidikan. Bumi Aksara.

Sukardi. (2014). Metodologi Penelitian Pendidikan. Bumi Aksara.

Susanto Ahmad. (2002). Teori Belajar dan Pembelajaran di Sekolah Dasar. Rineka Cipta.

SYAIFUL SAGALA. (2005). KONSEP DAN MAKNA PEMBELAJARAN. ALFABETA.

Triyanto. (2010). Metode Penelitian Pendidikan. UII Press. 
I20 | Tarbawi : Jurnal Pendidikan Islam Vol. 17. No. 2. Juli - Desember 2020 